\title{
AngII-induced glomerular mesangial cell proliferation inhibited by losartan via changes in intracellular calcium ion concentration
}

\author{
Guoying Qiu · Zequan Ji
}

Received: 31 December 2012/ Accepted: 21 February 2013/Published online: 5 March 2013

(c) The Author(s) 2013. This article is published with open access at Springerlink.com

\begin{abstract}
This study investigated the changes in intracellular $\left[\mathrm{Ca}^{2+}\right]^{\mathrm{i}}$ (intracellular calcium ion concentration) and TRPC6 (transient receptor potential channel 6) expression during angiotensin II (AngII)-induced glomerular mesangial cell (GMC) proliferation, as well as the inhibitory effect of losartan. GMC cultures were split into four groups treated for $24 \mathrm{~h}$ : Group N (blank control group), Group A $\left(10^{-7} \mathrm{~mol} / \mathrm{L}\right.$ AngII $)$, Group LT $\left(10^{-7} \mathrm{~mol} / \mathrm{L}\right.$ AngII and $10^{-5} \mathrm{~mol} / \mathrm{L}$ losartan $)$, and Group Pred $\left(10^{-7} \mathrm{~mol} / \mathrm{L}\right.$ AngII and $10^{-5} \mathrm{~mol} / \mathrm{L}$ prednisone). GMCs proliferation was measured by the MTT and trypan blue assays. The distribution of TRPC6 was monitored by immunofluorescence, the expression of TRPC6 was detected by RT-PCR and Western blotting, and $\left[\mathrm{Ca}^{2+}\right]^{\mathrm{i}}$ was measured by laser scanning confocal microscopy. The results showed that the maximal proliferation of GMCs was induced by treatment with $10^{-7} \mathrm{~mol} / \mathrm{L}$ AngII for $24 \mathrm{~h}$. In Group A, the distribution of TRPC6 was not uniform in the cell membrane, there was increased accumulation of this protein within the cytoplasm, and the increased expression of TRPC 6 and $\left[\mathrm{Ca}^{2+}\right]^{\mathrm{i}}$ was consistent with the proliferation of cells. In Group LT, losartan inhibited the proliferation of GMCs significantly, the levels of TRPC6 and $\left[\mathrm{Ca}^{2+}\right]^{i}$ were diminished, and the distribution of TRPC6 was improved. Prednisone also significantly inhibited the proliferation of GMCs and had no effects on the expression of TRPC6 and $\left[\mathrm{Ca}^{2+}\right]^{\mathrm{i}}$ in Group Pred. These findings suggested that AngII could enhance the expression of TRPC6, increase $\left[\mathrm{Ca}^{2+}\right]^{\mathrm{i}}$, and demonstrate a time-dose-response relationship with
\end{abstract}

G. Qiu · Z. Ji ( $\square)$

The Second Affiliated Hospital of Guangzhou Medical

University, No. 195 Dongfeng Xi Road,

Guangzhou 510182, China

e-mail: zeqj@yahoo.com.cn the proliferation of GMCs, while losartan reversed the effect of AngII on GMC proliferation.

Keywords Glomerular mesangial cell · Proliferation . Angiotensin II $\cdot$ TRPC6 $\cdot\left[\mathrm{Ca}^{2+}\right]^{\mathrm{i}}$

\section{Introduction}

In the past 20 years, epidemiological studies have suggested an increase in the incidence of chronic kidney disease in children [1]. Glomerulosclerosis is a pathological condition commonly found in chronic kidney diseases of different causes and is characterized by glomerular mesangial cell (GMC) proliferation and extracellular matrix (ECM) deposition. Therefore, there are numerous studies regarding GMC proliferation-related factors, which are important for making progress toward the reversal of glomerular injury.

Transient receptor potential channel (TRPC) is a transmembrane protein that allows for transmembrane movement of $\mathrm{Ca}^{2+}$. TRPC6 is the core member of TRPC superfamily [2,3], which maintains normal kidney function by regulating $\left[\mathrm{Ca}^{2+}\right]^{\mathrm{i}}$ (intracellular calcium ion concentration) and is involved in a number of kidney diseases $[4,5]$.Changes in intracellular calcium signaling pathways caused by mutations or abnormal expression of TRPC6 lead to various kidney proliferation diseases [6], such as focal segmental glomerulosclerosis (FSGS), minimal change disease (MCD), and membranous glomerulonephritis (MGN). These observations suggest that the relationship between TRPC 6 and $\mathrm{Ca}^{2+}$ is of great significance for the proliferation type of kidney diseases. Angiotensin II (AngII) can activate multiple signaling pathways through the AngII type I receptor (AT1R) and is involved in the 
regulation of TRPC6 as well as upregulating the expression of chemotactic factor, fibroblast growth factor, and adhesion molecule, thus contributing to pathological processes such as cell proliferation, inflammation, and fibrosis [7-9]. Previous research had shown that TRPC6 can promote the increase of AngII-related $\mathrm{Ca}^{2+}$ through AT1R to enhance damage caused by AngII [10]. Therefore, studies of the relationship among GMC ion channels $\left[\mathrm{Ca}^{2+}\right]^{\mathrm{i}}$ and the involvement of ion channels in cell proliferation have become hot topics. In this study, GMC proliferation induced by AngII was observed. The expression of TRPC6 at the gene and protein level, as well as the relationship between cell proliferation and $\left[\mathrm{Ca}^{2+}\right]^{\mathrm{i}}$ in the GMC proliferation process, was further investigated. Furthermore, the blocking effects of losartan were studied, and the mechanism of cell proliferation induced by AngII was explored from the perspective of ion channels.

\section{Materials and methods}

GMC proliferation and MTT (methyl thiazolyl tetrazolium) assay

Glomerular mesangial cells (HBZY-1, Experimental Animal Center in Sun Yat-sen University, China) were cultured in incubators containing $5 \% \mathrm{CO}_{2}$ at $37{ }^{\circ} \mathrm{C}$ and grew adherently in $20 \%$ fetal bovine serum medium (Gibco, USA). Morphology was observed with an inverted microscope. GMCs at logarithmic growth stage were inoculated into six-well plates, fixed with paraformaldehyde for $30 \mathrm{~min}$, and then blocked by goat serum (Gibco, USA) for 1 h. Afterward, GMCs were incubated with mouse monoclonal antibodies (1:50, Wuhan Boster, China), including anti-desmin protein, anti- $\alpha$-actin protein, anti-myosin protein, anti-vimentin protein, anti-keratin protein, and anti-factor VIII at $4{ }^{\circ} \mathrm{C}$ overnight. This was followed by inoculation with FITC-labeled goat anti-mouse $\operatorname{IgG}(1: 32$, Invitrogen, USA) at $37{ }^{\circ} \mathrm{C}$ for $1 \mathrm{~h}$. GMCs were monitored and visualized by fluorescence microscopy. GMCs of 3-8 generations were used for further experiments.

Cells were inoculated into 96-well plates. In the serumfree medium, cells adhered to the surface, and different concentrations of AngII (Sigma, USA), including 0 (blank control group), $10^{-8}$ and $10^{-7}, 10^{-6}$ and $10^{-5} \mathrm{~mol} / \mathrm{L}$, were used to stimulate the GMCs for $0,24,48$, and $72 \mathrm{~h}$, respectively. Next, $10 \mu \mathrm{L}$ of MTT $(5 \mathrm{mg} / \mathrm{mL}$, Sigma, USA) was added to each well and incubated at $37^{\circ} \mathrm{C}$ for $4 \mathrm{~h}$; afterward, $150 \mu \mathrm{L}$ of dimethyl sulfoxide (DMSO) was added to each well. The optical density (OD) at $490 \mathrm{~nm}$ was measured by a microplate reader. After mixing the cells with a $0.4 \%$ trypan blue solution (9:1, Wuhan Boster, China)for $3 \mathrm{~min}$, the number of living cells and dead cells were counted with a hemocytometer. Proliferation rate (\%) was calculated with the following formula: (OD value in AngII group - OD value in blank control group)/OD value in blank control $\times 100 \%$. Cell viability $(\%)$ was calculated with the following formula: number of living cells/ (number of living cells + number of dead cells) $\times 100 \%$.

After determining the optimal concentration and time of AngII treatment $\left(10^{-7} \mathrm{~mol} / \mathrm{L}\right.$ of AngII to induce GMC proliferation for $24 \mathrm{~h}$ ), the experiments were grouped as follows: Group N (blank control group), Group A $\left(10^{-7} \mathrm{~mol} / \mathrm{L}\right.$ AngII), Group LT $\left(10^{-7} \mathrm{~mol} / \mathrm{L}\right.$ AngII and $10^{-5} \mathrm{~mol} / \mathrm{L}$ losartan), and Group Pred $\left(10^{-7} \mathrm{~mol} / \mathrm{L}\right.$ AngII and $10^{-5} \mathrm{~mol} / \mathrm{L}$ prednisone). Intervention groups (Group LT and Group Pred) were pre-treated by losartan or prednisone, respectively, for $1 \mathrm{~h}$ prior to the addition of AngII. Inhibition rate $(\%)$ was calculated with the following formula: (OD value in group $\mathrm{A}-\mathrm{OD}$ value in intervention group)/OD value in group $\mathrm{A} \times 100 \%$.

\section{Distribution and expression of TRPC6}

\section{Immunofluorescence staining}

Cells in different groups were fixed with paraformaldehyde, blocked with goat serum (Gibco, USA), and mixed with rabbit anti-mouse TRPC6 polyclonal antibody (1:1000, Alomone Labs, Israel). After overnight incubation, FITC-labeled goat anti-rabbit IgG (1:200, Santa Cruz, USA) was added, and the distribution of TRPC6 was observed by immunofluorescence microscopy.

\section{Reverse transcription and real-time PCR}

Total RNA was extracted with the addition of Trizol reagent (Invitrogen, USA) into all groups. cDNA was synthesized using 1-2 $\mu \mathrm{g}$ of total RNA. The primers were designed using the Primer Express software (Primer Premier 5.0) based on sequences obtained with the GenBank accession numbers. The sequences of the primers and amplicon sizes are shown in Table 1. PCR amplification consisted of one cycle at $95{ }^{\circ} \mathrm{C}$ for $30 \mathrm{~s}$, followed by 40 cycles at $95{ }^{\circ} \mathrm{C}$ for $5 \mathrm{~s}$ and $60{ }^{\circ} \mathrm{C}$ for $20 \mathrm{~s}$. Agarose gel electrophoresis was employed to analyze PCR products. Optical density analysis with glyceraldehyde-3-phosphate dehydrogenase (GAPDH, Invitrogen, USA) serving as an internal reference was used to measure mRNA expression in all groups.

\section{Western blotting}

Cell lysis solution was added into the cells of each group. The protein concentration was determined by the bicinchoninic acid (BCA) method. Thirty five micrograms of total 
Table 1 Real-time PCR primer sequences and amplicon sizes

\begin{tabular}{llll}
\hline Gene & Primer sequences $\left(5^{\prime}-3^{\prime}\right)$ & $\begin{array}{l}\text { Size } \\
(\mathrm{bp})\end{array}$ & $\begin{array}{l}\text { Accession } \\
\text { no. }\end{array}$ \\
\hline TRPC6 & $\begin{array}{c}\text { F: TGG CAA GTC CAG CAT } \\
\text { ACC TGT C }\end{array}$ & 178 & NM 053559 \\
(Rattus) & $\begin{array}{l}\text { R: GTG TTT CTG CAG AGG } \\
\text { TCC AGG AG }\end{array}$ & & \\
GAPDH & $\begin{array}{l}\text { F: GGC ACA GTC AAG GCT } \\
\text { GAG AAT G }\end{array}$ & 143 & NM 017008 \\
(Rattus) & $\begin{array}{l}\text { R: ATG GTG GTG AAG ACG } \\
\text { CCA GTA }\end{array}$ & & \\
& & & \\
&
\end{tabular}

protein was denatured at $100{ }^{\circ} \mathrm{C}$ for $5 \mathrm{~min}$, run on a $120 \mathrm{~g} /$ L sodium dodecyl sulfate polyacrylamide gel (SDS-PAGE, Invitrogen, USA) for $1.5 \mathrm{~h}$, and then wet transferred to a polyvinylidene difluoride (PVDF, Invitrogen, USA) membrane. The membrane was blocked with $5 \%$ non-fat milk at room temperature for $30 \mathrm{~min}$, followed by incubation with rabbit anti-mouse TRPC6 polyclonal antibody (1:1000, Alomone Labs, Israel) at $4{ }^{\circ} \mathrm{C}$ overnight. The membrane was subsequently incubated with HRP-labeled goat anti-rabbit IgG (1:5000, Wuhan Boster, China) at room temperature for $1 \mathrm{~h}$. After the final rinse, the membrane was visualized with an enhanced chemiluminescence reagent and exposed to X-ray films. Band intensity was estimated using Gel-Pro image analysis software. The relative expression levels of target proteins were calculated as the ratio of the target protein band intensity to that of the internal control GAPDH.

\section{Intracellular $\left[\mathrm{Ca}^{2+}\right]^{\mathrm{i}}$}

Cells from each group were re-suspended with $5 \times 10^{-6} \mathrm{~mol} / \mathrm{L}$ of Fluo-3AM (Invitrogen, USA) at $37{ }^{\circ} \mathrm{C}$ for $45 \mathrm{~min}$. Following this step, cells were inoculated into special culturing dishes for laser scanning confocal microscope (LSCM) and washed with D-Hanks three times. Then, the measurements were taken by LSCM with the excitation wavelength set at $488 \mathrm{~nm}$. The $\left[\mathrm{Ca}^{2+}\right]^{\mathrm{i}}$ was scanned per $5 \mathrm{~s}$ for $10 \mathrm{~min}$, with each scan covering 20 cells. The results were analyzed by Zeiss image 4.2 software. The $\left[\mathrm{Ca}^{2+}\right]^{\mathrm{i}}$ was calculated with the following formula: F/Fa (F: real-time fluorescence intensity; Fa: basic fluorescence intensity).

\section{Statistical analyses}

All values were expressed as mean $\pm \mathrm{SD}$, and analysis of variance was calculated using SPSS 11.5 statistical analysis software. Fisher's LSD test was used for the pairwise comparison. A $P$ value $<0.05$ was considered to be statistically significant.

\section{Results}

Morphology and identification of GMC

GMCs grew adherently and showed larger soma with fusiform, irregular star-shaped, or elongated shapes. There were several dendrites of various lengths on the cell, which connected the cell groups into a network with a round- or egg-shaped cell nuclei in the middle. The GMCs stained positive for desmin, $\alpha$-Actin, myosin, and vimentin and negative for keratin and factor VIII, indicating that the cultured cells were in fact GMCs (Fig. 1).

\section{Cell proliferation results}

There was no obvious cell proliferation induced by the addition of $10^{-8} \mathrm{~mol} / \mathrm{L}$ AngII, while addition of $10^{-7}$, $10^{-6}$, and $10^{-5} \mathrm{~mol} / \mathrm{L}$ of AngII caused increased cell proliferation at 24,48 , and $72 \mathrm{~h}$; the proliferation at $24 \mathrm{~h}$ was much more significant than that at $48 \mathrm{~h}$ and $72 \mathrm{~h}$ $(P<0.01, P<0.05)$. In addition, at $24 \mathrm{~h}$, the proliferation with AngII at $10^{-7} \mathrm{~mol} / \mathrm{L}$ was of greater statistical significance than that observed with AngII at $10^{-8}, 10^{-6}$, and $10^{-5} \mathrm{~mol} / \mathrm{L}(P<0.01)$ (Table 2$)$. After staining with trypan blue, dead cells turned into the color of light blue while living cells kept unchanged in color. The cell viability for cells treated with $10^{-7} \mathrm{~mol} / \mathrm{L}$ AngII at $24 \mathrm{~h}$ was $91-95 \%$, while cell viabilities of 80-86 and 60-68\% were observed when cells were treated with $10^{-6}$ and $10^{-5} \mathrm{~mol} / \mathrm{L}$ of AngII, respectively. Compared with Group N, the increases in GMC proliferation in Group A, Group LT, and Group Pred were statistically significant $(P<0.01, P<0.05)$. Furthermore, compared with Group A, the GMC proliferation was significantly inhibited in Group LT and Group Pred (39.5 and $49.6 \%, P<0.05)$ (Table 3).

\section{TRPC6 expression}

\section{TRPC6 distribution}

In Group N, TRPC6 was detected mostly in the cell membrane, where it was uniformly distributed and showed little staining in the cytoplasm (Fig. 2a). After introduction of AngII for $24 \mathrm{~h}$ (Group A), the distribution of TRPC6 was no longer homogeneous in the membrane, and some region showed a lack of TPRC6 staining; additionally, 

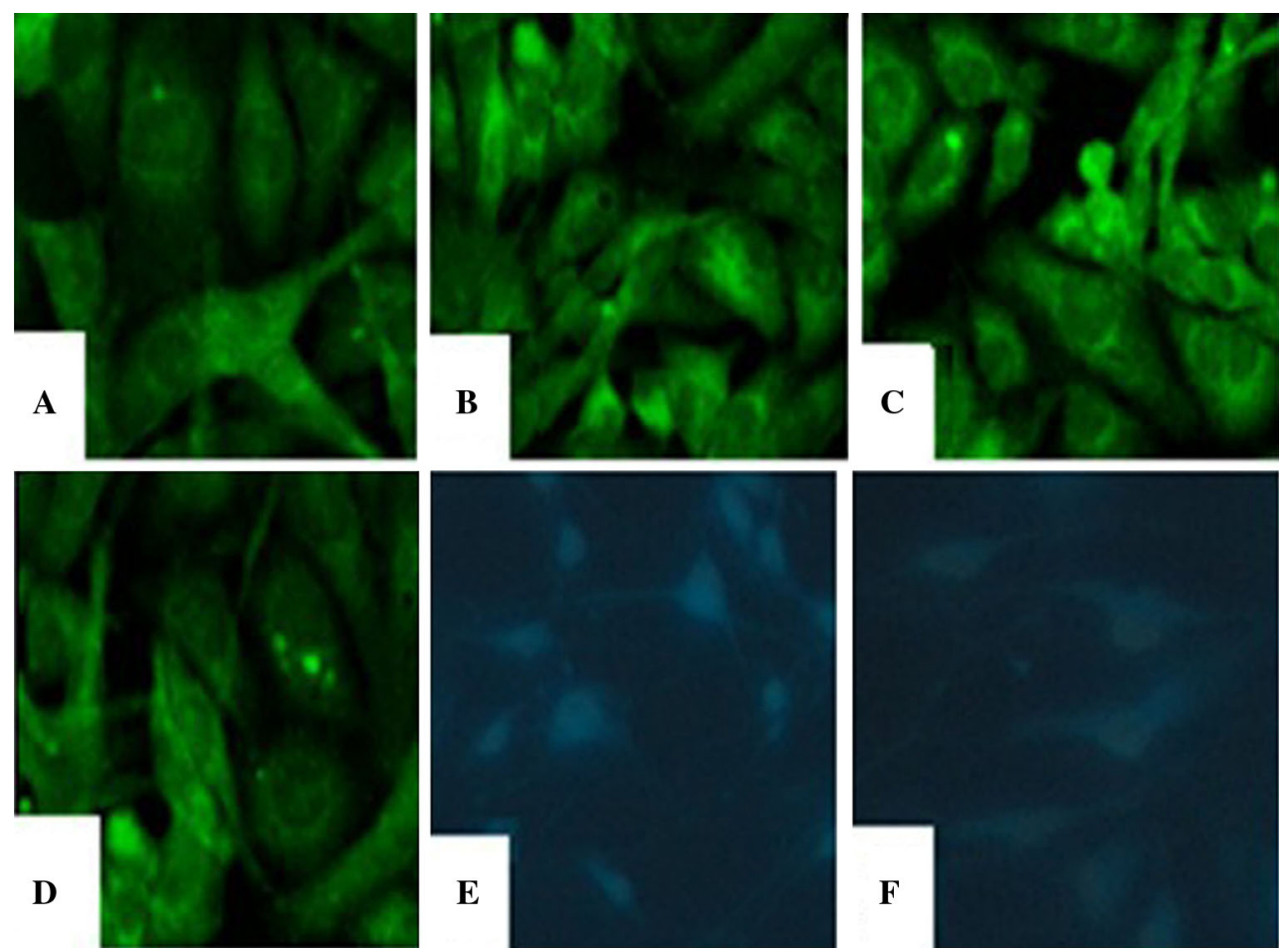

Fig. 1 Images of immunofluorescence staining for GMC $(\times 400)$. a Desmin $(+)$; b a-Actin $(+)$; c Myosin $(+)$; d Vimentin(+); e Keratin $(-)$; f Factor VIII (-) (Blue color was DAPI nuclei staining, the target protein $(-)$ ) (color figure online)

Table 2 Changes in GMC proliferation induced by AngII (mean \pm SD)

\begin{tabular}{lllll}
\hline Groups $(\mathrm{mol} / \mathrm{L})$ & $0 \mathrm{~h}$ & $24 \mathrm{~h}$ & $48 \mathrm{~h}$ & $72 \mathrm{~h}$ \\
\hline 0 & $0.147 \pm 0.016$ & $0.230 \pm 0.021$ & $0.161 \pm 0.020$ & $0.162 \pm 0.017$ \\
$10^{-8}$ & $0.149 \pm 0.013$ & $0.298 \pm 0.014(29.6 \%)$ & $0.217 \pm 0.018(34.4 \%)$ & $0.202 \pm 0.015(92.3 \%)$ \\
$10^{-7}$ & $0.152 \pm 0.027$ & $0.699 \pm 0.012(203.6 \%)^{* * \# \# \triangle \mathrm{abc}}$ & $0.349 \pm 0.025(116.1 \%)^{* *}$ & $0.470 \pm 0.016(189.8 \%)^{* *}$ \\
$10^{-6}$ & $0.152 \pm 0.018$ & $0.411 \pm 0.021(78.6 \%)^{* \# \triangle}$ & $0.330 \pm 0.022(104.4 \%)^{*}$ & $0.291 \pm 0.019(79.6 \%)^{*}$ \\
$10^{-5}$ & $0.151 \pm 0.022$ & $0.421 \pm 0.019(83.1 \%)^{* \# \triangle}$ & $0.338 \pm 0.019(109.7 \%)^{*}$ & $0.281 \pm 0.018(73.5 \%)^{*}$ \\
\hline
\end{tabular}

(\%) Proliferation rate; versus Group $0 \mathrm{~mol} / \mathrm{L}, * P<0.05$, ** $P<0.01$; Group $24 \mathrm{~h}$ versus $48 \mathrm{~h},{ }^{*} P<0.05$, ${ }^{\#} P<0.01$; Group $24 \mathrm{~h}$ versus $72 \mathrm{~h},{ }^{\triangle} P<0.05, \triangle \triangle P<0.01$; Group $24 \mathrm{~h} 10^{-7}$ versus $24 \mathrm{~h} 10^{-8}$

a $P<0.01$; Group $24 \mathrm{~h} 10^{-7}$ versus $24 \mathrm{~h} 10^{-6},{ }^{\mathrm{b}} P<0.01$; Group $24 \mathrm{~h} 10^{-7}$ versus $24 \mathrm{~h} 10^{-5},{ }^{\mathrm{c}} P<0.01$

Table 3 Inhibitory effects of losartan and prednisone on GMC proliferation (mean $\pm \mathrm{SD})$

\begin{tabular}{|c|c|c|}
\hline Groups & $24 \mathrm{~h}$ & $\begin{array}{l}\text { Inhibition rate } \\
(\%)\end{array}$ \\
\hline $\mathrm{N}$ & $0.224 \pm 0.020$ & \\
\hline A (AngII $\left.10^{-7} \mathrm{~mol} / \mathrm{L}\right)$ & $0.691 \pm 0.019^{* *}$ & \\
\hline $\begin{array}{l}\mathrm{LT}\left(\text { AngII } 10^{-7} \mathrm{~mol} / \mathrm{L}+\mathrm{LT}\right. \\
\left.10^{-5} \mathrm{~mol} / \mathrm{L}\right)\end{array}$ & $0.418 \pm 0.021{ }^{* \#}$ & $39.5 \%$ \\
\hline $\begin{array}{l}\text { Pred (AngII } 10^{-7} \mathrm{~mol} / \mathrm{L}+ \\
\left.\text { Pred }^{-5} \mathrm{~mol} / \mathrm{L}\right)\end{array}$ & $0.348 \pm 0.018^{* \#}$ & $49.6 \%$ \\
\hline
\end{tabular}

Versus Group N, * $P<0.05,{ }^{* *} P<0.01$; versus Group A, ${ }^{\#} P<0.05$

more TRPC6 was detected in cytoplasm, and even particles were observed (Fig. 2b). Compared with Group A, after treatment by losartan (Group LT), the distribution of
TRPC6 was more uniform and improved (Fig. 2c). After the incubation with prednisone (Group Pred), the distribution of TRPC6 was similar to that observed in Group A, with some regions along cell membrane missing TPRC6 and more appearing in cytoplasm (Fig. 2d).

\section{TRPC6 mRNA expression}

The expression of TRPC6 mRNA and GAPDH mRNA was measured (Fig. 3). Compared with Group N, the expression of TRPC6 at the mRNA level in Group A, Group LT, and Group Pred was elevated $(P<0.01)$; when compared with Group A, the expression of TRPC6 mRNA in Group LT was diminished $(P<0.01)$, and there existed no significant difference in Group Pred $(P>0.05)$ (Fig. 5). 

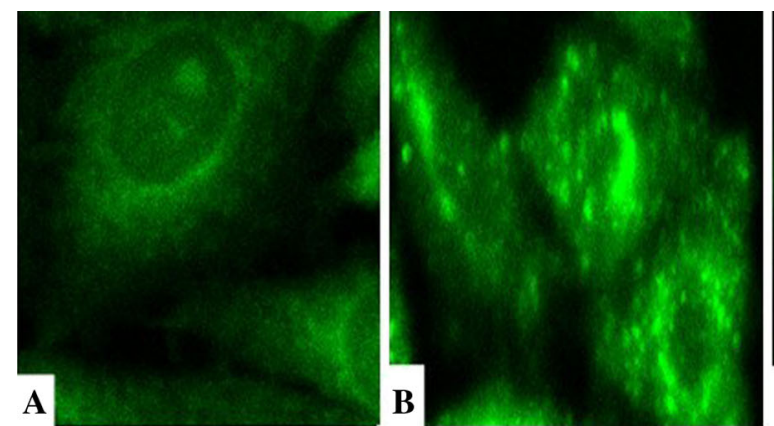

Fig. 2 Distribution images of TRPC6 in GMC $(\times 600)$. a Group N: TRPC6 was uniformly distributed in cell membrane and cytoplasm, most in cell membrane and few in cytoplasm; b Group A: TRPC6 distribution was not continuous along membrane, with some membrane region missing of TPRC6; more TRPC6 appeared in cytoplasm,

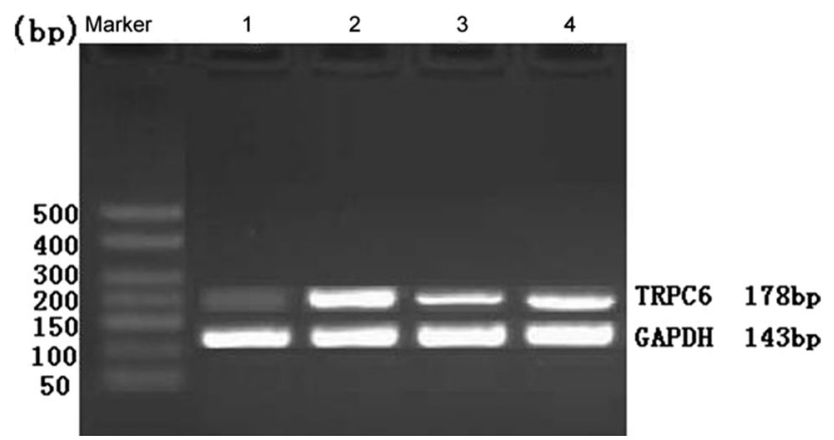

Fig. 3 Expression of GMC TRPC6 mRNA in different groups. 1 Group N; 2 Group A; 3 Group LT; 4 Group Pred

\section{TRPC6 protein expression}

The proteins measured by immunoblotting were the $106 \mathrm{kDa}$ TRPC6 protein and the $37 \mathrm{kDa}$ GAPDH protein (Fig. 4). The expression of the TRPC6 protein in Group A, Group LT, and Group Pred was higher than that in Group $\mathrm{N}$ $(P<0.01)$; as compared with Group A, the expression of TRPC6 protein in Group LT declined $(P<0.01)$, and no significant difference in Group Pred was observed $(P>0.05)$ (Fig. 5).

\section{Changes of $\left[\mathrm{Ca}^{2+}\right]^{\mathrm{i}}$}

After incubation with Fluo-3AM, a calcium indicator, green fluorescence was uniformly distributed in cells (Fig. 6). The $\left[\mathrm{Ca}^{2+}\right]^{\mathrm{i}}$ increased significantly after the addition of AngII. The fluorescence intensity began to increase at the third min and peaked at the fourth minute. The fluorescence began to decrease $1 \mathrm{~min}$ later and returned to the starting level at the eighth minute (Fig. 7). At the fourth min, $\left[\mathrm{Ca}^{2+}\right]^{\mathrm{i}}$ in Group A, Group LT, and Group Pred were higher than that in Group N $(P<0.01)$; as compared with Group A, $\left[\mathrm{Ca}^{2+}\right]^{\mathrm{i}}$ decreased in Group LT
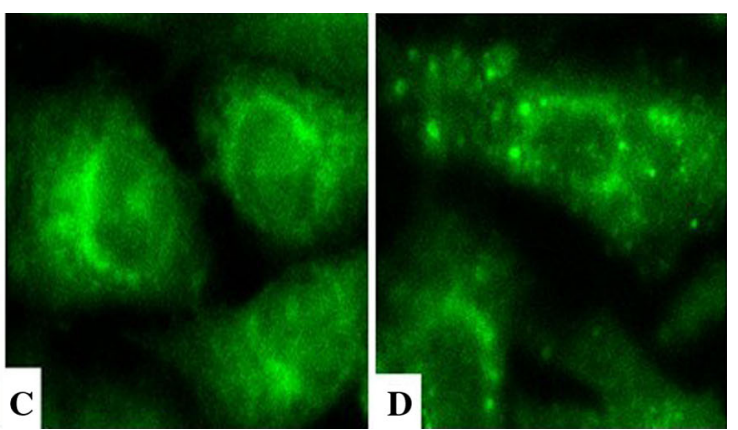

even particles can be observed; c Group LT: TRPC6 distribution was more uniform and improved than that in group A; d Group Pred: TRPC6 distribution was similar as in group A, with some regions along cell membrane missing and more in cytoplasm

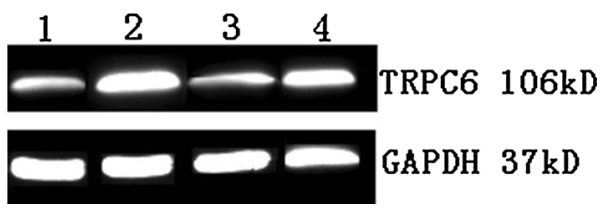

Fig. 4 Electrophoresis for TRPC6 protein of GMC in different groups. 1 Group N; 2 Group A; 3 Group LT; 4 Group Pred

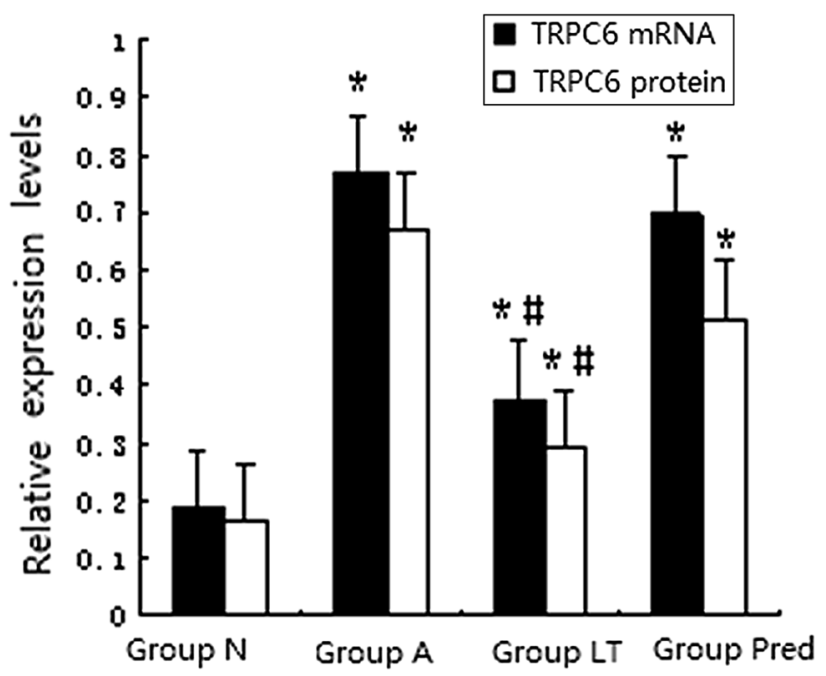

Fig. 5 The analysis of TRPC6 mRNA and protein of GMC in different groups. Versus Group $\mathrm{N}, * P<0.01$; versus Group A, ${ }^{\#} P<0.01$

$(P<0.05)$, and there was no significant difference in Group Pred $(P>0.05)$.

\section{Discussion}

The characteristic pathological features of early-stage glomerulosclerosis are excessive proliferation of GMCs and secretion of large amounts of ECM in the glomerulus, 

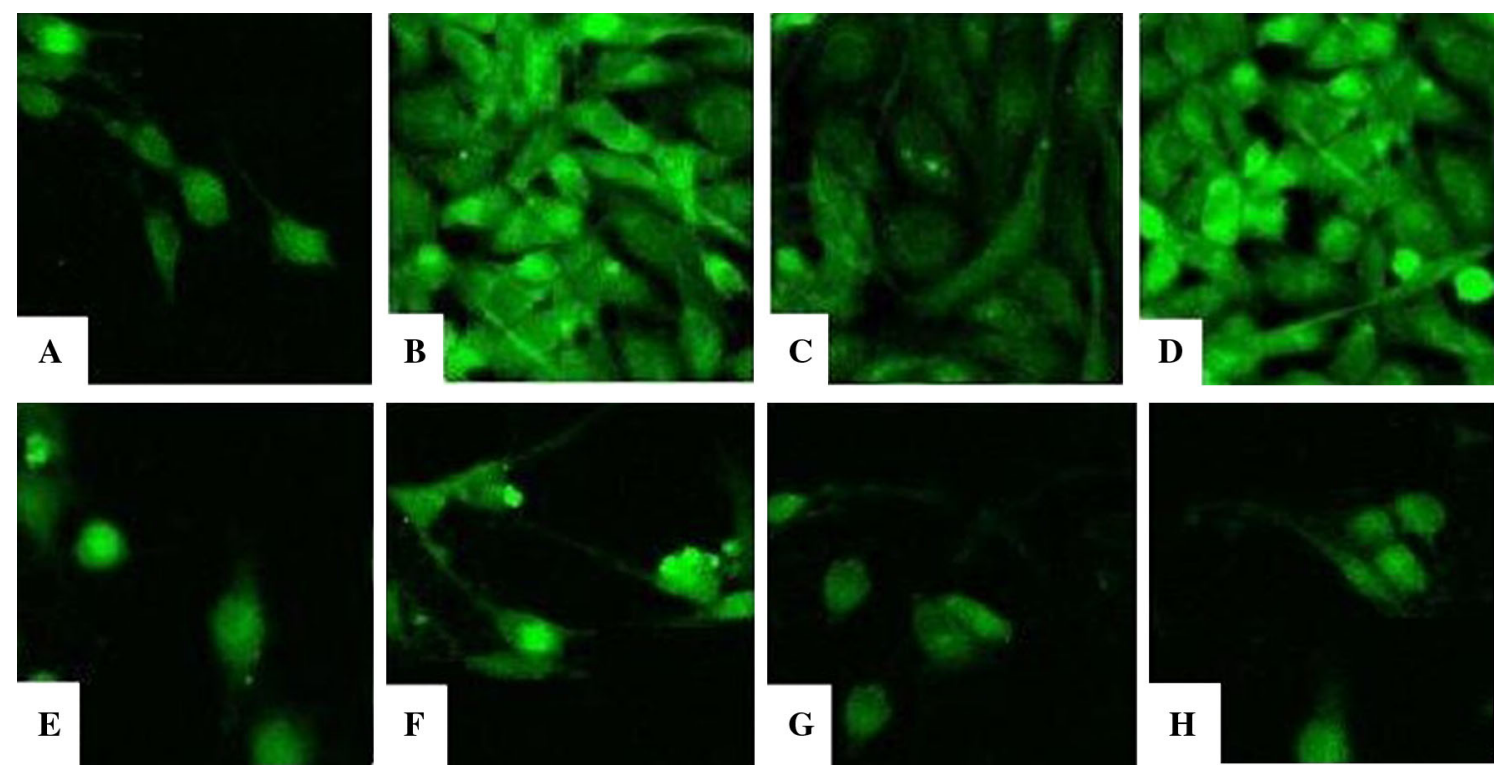

Fig. 6 Distribution of $\left[\mathrm{Ca}^{2+}\right]^{\mathrm{i}}$ for GMC at $4 \min$ and $8 \min (\times 400)$. a Group $\mathrm{N}$ at $4 \min$; b Group A at 4 min; c Group LT at 4 min; d Group Pred at $4 \mathrm{~min}$; e Group $\mathrm{N}$ at $8 \mathrm{~min}$; $\mathbf{f}$ Group A at $8 \mathrm{~min} ; \mathbf{g}$ Group LT at $8 \mathrm{~min} ; \mathbf{h}$ Group Pred at 8 min

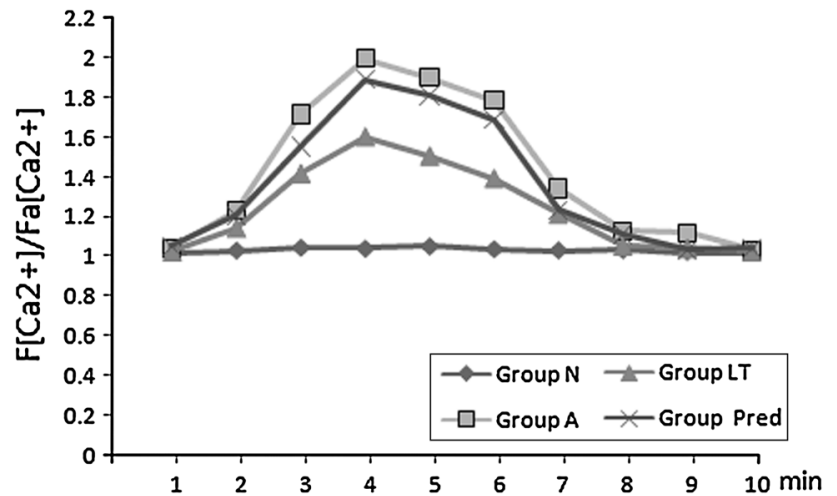

Fig. 7 Changes of $\left[\mathrm{Ca}^{2+}\right]^{\mathrm{i}}$ in $\mathrm{GMC}$ in different groups

which eventually leads to glomerulosclerosis-induced renal failure. As the main active substances in the kidney, AngII can enhance the mRNA and protein expression of transforming growth factor-beta and fibrinolytic enzyme activator inhibitor, causing GMC proliferation and ECM accumulation that gradually leads to glomerulosclerosis.

In this study, the cell proliferation was indirectly measured by the methyl thiazolyl tetrazolium assay, which detected the activity of mitochondrial metabolic enzymes, in order to measure AngII-induced GMC proliferation. The results showed that at concentrations of $10^{-7}, 10^{-6 \text {, }}$ and $10^{-5} \mathrm{~mol} / \mathrm{L}$, AngII promoted the proliferation of GMCs during the $0-48 \mathrm{~h}$ time frame after treatment; there was an apparent time-dose-response relationship, especially for $10^{-7} \mathrm{~mol} / \mathrm{L}$ AngII at $24 \mathrm{~h}$. When the concentration of AngII was increased to $10^{-5} \mathrm{~mol} / \mathrm{L}$, which was at $72 \mathrm{~h}$, the cell proliferation delayed, which indicated that
AngII affected not only cell proliferation, but also cell apoptosis. AngII receptors mainly include AT1R and AT2R; AT1R mainly affects cell proliferation and smooth muscle contraction, while AT2R affects cell apoptosis and smooth muscle relaxation [11]. Within certain concentrations of AngII, AT1R in GMCs plays the leading role, so the effect of AngII is mainly cell proliferation. At higher concentrations, where the number of AngII exceeds the number of AT1R binding sites, the function of AT2R comes into play. In this study, when compared with Group Pred, losartan significantly inhibited proliferation of GMCs, which suggested that by blocking the binding between AngII and AT1R, cell proliferation could be effectively inhibited.

Intracellular $\mathrm{Ca}^{2+}$ is as an important second messenger in the process of cell proliferation, and the changes in concentration trigger the transduction of growth-related signals. An increase of $\left[\mathrm{Ca}^{2+}\right]^{\mathrm{i}}$ can promote the proliferation of GMCs; for example, AngII can increase $\left[\mathrm{Ca}^{2+}\right]^{\mathrm{i}}$ by signal transduction pathways, which in turn regulates cell proliferation [12, 13]. After treatment with a calcium chelator, the increase of $\left[\mathrm{Ca}^{2+}\right]^{\mathrm{i}}$ and the proliferation of GMCs are significantly inhibited [14]. The same inhibitory effect was shown for losartan in this study. Store-operated calcium channels (SOCC) participate in signal transduction as major regulators of $\mathrm{Ca}^{2+}$ internal flow in kidney microvascular smooth muscle cells and GMCs. TRPC1/3/4/6 of GMCs are candidates for SOCC [15]. Through SOCC and other types of calcium channels, AngII can affect intracellular $\mathrm{Ca}^{2+}$, thereby regulating renal microcirculation and GMC functions [16]. 
In this study, it was observed that AngII not only stimulated the proliferation of GMCs, but also significantly affected the distribution of TRPC6 and its expression at the mRNA and protein level. Measurements with a confocal microscope indicated that $\left[\mathrm{Ca}^{2+}\right]^{\mathrm{i}}$ reached the maximum level at the forth minute after incubation with AngII. These observations suggested that TRPC6 and $\mathrm{Ca}^{2+}$ played important roles in the process of GMC proliferation. After incubation with losartan, TRPC6 distribution was improved, and $\left[\mathrm{Ca}^{2+}\right]^{\mathrm{i}}$ was consistent with the cell proliferation, indicating that AngII affected TRPC6 and $\mathrm{Ca}^{2+}$ through AT1R, and further regulated cell proliferation. Prednisone inhibited cell proliferation, but had no effect on the expression of TRPC6 and $\left[\mathrm{Ca}^{2+}\right]^{\mathrm{i}}$, indicating that cell proliferation was not necessarily caused by changes in $\left[\mathrm{Ca}^{2+}\right]^{\mathrm{i}}$. It had been reported that glucocorticoid does not cause the changes in $\left[\mathrm{Ca}^{2+}\right]^{\mathrm{i}}$, and that its effects on cell proliferation could be achieved by inhibiting nuclei factor NF- $\kappa \mathrm{B}$ or increasing P21 protein to arrest the cell cycle of GMCs at $\mathrm{G}_{0} / \mathrm{G}_{1}[17,18]$.

AngII promoted the increase of $\left[\mathrm{Ca}^{2+}\right]^{\mathrm{i}}$ in $\mathrm{GMCs}$, which in turn induced its proliferation. The mechanism by which this occurs begins with the binding of AngII to AT1R on the surface of GMCs, which causes phospholipase c (PLC) to catalyze the cleavage of 4,5-phosphatidyl inositol diphosphate (PIP2), producing 1,4,5-inositol triphosphate (IP3). IP3 can then activate $\mathrm{Ca}^{2+}$ channels, leading the flow of extracellular $\mathrm{Ca}^{2+}$ into the cell. This influx results in increased $\left[\mathrm{Ca}^{2+}\right]^{\mathrm{i}}$ in the sarcoplasm, which in turn regulates transcription and causes the proliferation of GMCs. There exist target sites for AngII on the TRPC6 channel. Through TRPC6, $\left[\mathrm{Ca}^{2+}\right]^{\mathrm{i}}$ can be increased by AngII stimulation. And it is possible that TRPC6 and AngII are relevant in terms of regulating GMC proliferation via controlling $\left[\mathrm{Ca}^{2+}\right]^{\mathrm{i}}[19]$. In the case of receptor-regulating TRPC6 signaling pathways, high IP3 causes the release of sensitive calcium stores that further activate TRPC6, which leads an influx of $\mathrm{Ca}^{2+}$ into the cells to fill the calcium stores, so TRPC6 is considered a candidate for SOCC and plays the role of a SOCC [20]. These studies suggested that the mechanism by which AngII promoted the increase of $\left[\mathrm{Ca}^{2+}\right]^{\mathrm{i}}$ and induced GMC proliferation shared similarities with the mechanism by which TRPC6 regulated $\left[\mathrm{Ca}^{2+}\right]^{i}$, as both were associated with an IP3-regulated calcium channel, and TRPC6 mediated $\mathrm{Ca}^{2+}$ to flow inward to promote the proliferation of GMCs.

Acknowledgments This study was supported by the Natural Science Foundation of Guangdong Province (S2012010008588), Scientific and Technical Innovation Program for Higher School of Education Department of Guangdong Province (2012KJCX0088), and Scientific Research Program of Guangzhou Education Bereau (10A254).

Conflict of interest None.
Open Access This article is distributed under the terms of the Creative Commons Attribution License which permits any use, distribution, and reproduction in any medium, provided the original author(s) and the source are credited.

\section{References}

1. Lanewala A, Mubarak M, Kazi JI et al (2012) A clinicopathologic study of primary focal segmental glomerulosclerosis in children. Saudi J Kidney Dis Transpl 23(3):513-520

2. Winn MP, Conlon PJ, Lynn KL et al (2005) A mutation in the TRPC6 cation channel causes familial focal segmental glomerulosclerosis. Science 308(5729):1801-1804

3. Reiser J, Polu KR, Möller CC et al (2005) TRPC6 is a glomerular slit diaphragm-associated channel required for normal renal function. Nat Genet 37(7):739-744

4. Mir S, Yavascan O, Berdeli A et al (2012) TRPC6 gene variants in Turkish children with steroid-resistant nephrotic syndrome. Nephrol Dial Transpl 27(1):205-209

5. Liu Y, Ji Z (2012) FK506 alleviates proteinuria in rats with adriamycin-induced nephropathy by down-regulating TRPC6 and CaN expressions. J Nephrol 25(6):918-925

6. Schlöndorff JS, Pollak MR (2006) TRPC6 in glomerular health and disease: what we know and what we believe. Semin Cell Dev Biol 17(6):667-674

7. Ji Z, Huang C, Liang C et al (2005) Protective effects of blocking renin-angiotensin system on the progression of renal injury in glomerulosclerosis. Cell Mol Immunol 2(2):150-154

8. Li Y, Tan X, Dai C et al (2009) Inhibition of integrin-linked kinase attenuates renal interstitial fibrosis. J Am Soc Nephrol 20(9):1907-1918

9. Ruiz-Ortega M, Rupérez M, Esteban V et al (2006) Angiotensin II: a key factor in the inflammatory and fibrotic response in kidney disease. Nephrol Dial Transpl 21(1):16-20

10. Eckel J, Lavin PJ, Finch EA et al (2011) TRPC6 enhances angiotensin II-induced albuminuria. J Am Soc Nephrol 22(3):526-535

11. Williams PJ, Mistry HD, Innes BA et al (2010) Expression of AT1R, AT2R and AT4R and their roles in extravillous trophoblast invasion in the human. Placenta 31(5):448-455

12. Feng Z, Wei C, Chen X et al (2006) Essential role of $\mathrm{Ca}^{2+}$ release channels in angiotensin II-induced $\mathrm{Ca}^{2+}$ oscillations and mesangial cell contraction. Kidney Int 70(1):130-138

13. Mehta PK, Griendling KK (2007) Angiotensin II cell signaling: physiological and pathological effects in the cardiovascular system. Am J Physiol Cell Physiol 292(1):C82-C97

14. Saleh H, Schlatter E, Lang D et al (2000) Regulation of mesangial cell apoptosis and proliferation by intracellular $\mathrm{Ca}(2+)$ signals. Kidney Int 58(5):1876-1884

15. Sours S, Du J, Chu S et al (2006) Expression of canonical transient receptor potential (TRPC) proteins in human glomerular mesangial cells. Am J Physiol Renal Physiol 290(6):F1507F1515

16. Ma R, Pluznick JL, Sansom SC (2005) Ion channels in mesangial cells: function, malfunction, or fiction. Physiology (Bethesda) 20:102-111

17. Bladh LG, Lidén J, Pazirandeh A et al (2005) Identification of target genes involved in the antiproliferative effect of glucocorticoids reveals a role for nuclear factor-(kappa)B repression. Mol Endocrinol 19(3):632-643

18. Ploner C, Schmidt S, Presul E et al (2005) Glucocorticoidinduced apoptosis and glucocorticoid resistance in acute lymphoblastic leukemia. J Steroid Biochem Mol Biol 93(2-5): $153-160$ 
19. Shi J, Ju M, Saleh SN et al (2010) TRPC6 channels stimulated by angiotensin II are inhibited by TRPC1/C5 channel activity through a $\mathrm{Ca}^{2+}$ and PKC-dependent mechanism in native vascular myocytes. J Physiol 588(19):3671-3682
20. Liao Y, Plummer NW, George MD et al (2009) A role for Orai in TRPC-mediated $\mathrm{Ca}^{2+}$ entry suggests that a TRPC: Orai complex may mediate store and receptor operated $\mathrm{Ca}^{2+}$ entry. PNAS 106(9):3202-3206 